\title{
Opting in or opting out in class action proceedings: from principles to pragmatism?
}

\author{
Estelle Hurter \\ $B A L L M L L D$ \\ Professor of Law, Department of Criminal and Procedural Law, University of South \\ Africa.
}

\begin{abstract}
OPSOMMING
Intree of uitree in klasaksie-gedinge: van beginsels na pragmatisme?

Die groepsdefinisie is een van die belangrikste aspekte van 'n groepsgeding. Nie alleen is hierdie definisie deurslaggewend ten aansien die bepaling van lidmaatskap van groep nie, maar is ook bepalend ten aansien van die kennisgewing aan die potensiële lede van die groep wat hulle moet inlig aangaande die groepsgeding en hulle in staat moet stel om te besluit om deel te hê aan die groep of nie. Hierdie artikel ondersoek die twee gebruiklike metodes (die sg 'opt-in' en die 'opt-out' model) in gebruik in sekere gemeneregjurisdiksies wat dien as meganisme om die samestelling van die groep te bepaal. In die proses word aandag geskenk aan die komplekse afweeg van fundamentele prosesregtelike beginsels en beleidsoorwegings wat in die gedrang kom by die maak van die keuse. Die Suid-Afrikaanse groepsgedingbestel is nog nie volledig ontwikkel nie, en gevolglik word daar hiermee gepoog om 'n bydrae te lewer in die soeke na die mees geskikte model vir Suid-Afrika.
\end{abstract}

\section{Introduction}

The manner in which a class is defined determines class membership. The class definition is, therefore, of utmost importance in class action proceedings, as not only will the class action judgment be binding on all those individuals who have been described or defined as members of the class, but it will also determine how the requisite notice to potential members should be framed, informing them of the class action to enable them to decide to either remain in the class or to opt out, or where applicable, to actively take steps to become part of the class (opt in).

Although there are many aspects regarding the class definition (such as over-inclusiveness and the moment of class closure) that are problematic and worth exploring separately, the focus of this article is on

* This article is based on work supported financially by the National Research Foundation. Any opinion, findings and conclusions or recommendations expressed in this material are those of the author and therefore the NRF does not accept any liability in regard to them. 
the method or choice of model to be used to determine class composition. Even a cursory review of international literature reveals that the debate surrounding the opt-in and opt-out option in the various class action regimes is far from settled. So for example, although federal class actions in America follow the opt-out model, critics favour the optin model, while Britain's opt-in Group Litigation Order seems set to be challenged by the Consumer Rights Act 2015. ${ }^{1}$ Past debates have been spirited and partisan, and have often been used as opportunities to revisit the bimodal debate ${ }^{2}$ over the class action procedure itself and to continue its vilification. ${ }^{3}$

More recently the question regarding the feasibility of a common ground (thus a move away from the bimodal position regarding the opting mechanism), was raised, ${ }^{4}$ and a hybridised form thereof was put forward. Although this suggestion is not novel (the existence of numerous mechanism configurations has been acknowledged in the past), ${ }^{5}$ it could re-ignite the American debate. Whether such debates will merely remain ongoing debates, or whether they could be harbingers of an actual reconsideration of the option mechanism to be employed in some jurisdictions, the timing is fortuitous. The South African class action is still developing and the option mechanism has so far only fleetingly received attention. An analysis of the bimodal approach is thus warranted, and could contribute towards the further development of our class action procedure.

The focus of this article is not the debate regarding which one of the two options is superior (that debate which includes lengthy lists of perceived pros and cons has been waged eloquently by erudite and eminent scholars in the field), but is rather the attempt to establish what considerations should inform the selection of the most appropriate option for the developing framework regulating the South African class action regime. Part 2 of this article provides an explanation of key concepts as well as an outline of the models currently available in some common law jurisdictions such as the United States, Canada and Australia. (Although Britain does, strictly speaking, not have a class action, the British position will be included here due to certain relevant

1 The launch of the first United Kingdom opt-out class action under this Act has taken place in March 2016: see Shearman \& Sterling LLP client publication 'Launch of first UK opt-out class action' 11 March 2016 available at http://www.shearman.com/en/newsinsights/publications/2016/03/launch -of-first-uk-opt-out-class-action-AT-031116.pdf (accessed 2016-08-10).

2 The class action is either supported or rejected.

3 See eg Redish Wholesale justice: constitutional democracy and the class action lawsuit (2009) 174-175231.

4 See Dodson 'An opt-in option for class actions' 2016 Michigan Law Review 171 .

5 See Mulheron 'Opting in, opting out, and closing the class: some dilemmas for England's class action lawmakers' 2010 Canadian Business Law Journal 376 379-401 where she discusses some ten potential models.

6 See Mukaddam v Pioneer Foods (Pty) Ltd 20132 SA 254 (SCA) 258F-G. and more recently Nkala $v$ Harmony Gold Mining Co Ltd 20165 SA 240 (GJ). 
points of contact.) In Part 3 the dilemma associated with the choice of option will be considered, and policy considerations that should inform the choice will be discussed in Part 4. Part 5 contains the main conclusions arrived at.

\section{Choices Made in Common Law Jurisdictions}

The non-hybridised ${ }^{7}$ 'opt out' class does not require a class member following certification ${ }^{8}$ to take a formal step (such as a formal consent by letter or other document) in order to be bound by the final outcome of a class action - a member simply need not do anything at all. ${ }^{9}$ Once a class member falls within the ambit of a particular group definition, the default position for his or her inertia is class membership. (Unsurprisingly this state of affairs has given rise to the epithet 'free riders' 10 to describe members of an opt-out class!) The class will normally remain 'widelydrawn' ${ }^{11}$ during the course of the action. Should a member not wish to be bound by the outcome of the action and to share in any resultant benefit, that member is required to take affirmative action to withdraw from the class, but retains the right to commence individual action. Such a right of withdrawal (or exclusion) necessarily requires that adequate notice be given to all members informing them of the action and of the opportunity to withdraw from the litigation. When drafting this notice the class definition is important, as it enables class members to determine whether or not they are class members. ${ }^{12}$

By contrast, a 'true' or purely 'opt in' class requires a class member to take affirmative action following certification, usually in the form of a prescribed step within a prescribed period in order to be included in the class, to ultimately be bound by the final outcome and to share in any resultant benefit if the action is successful. Because of the affirmative action on the part of class members, they are identified by name (rather

7 This description excludes the options in terms of which a court requires action to be taken by the class members that in effect amounts to requiring them to opt in (such as filing proof of claim forms) and where the option affords the court a discretion to decide whether a right of exclusion should extend to all or some members.

8 Certification refers to the preliminary process whereby a court assesses whether the threshold criteria for commencing a class action in a particular jurisdiction have been met. However, not all class action regimes require certification: see iro the Australian position Mulheron The class action in common law legal systems (2004) 24-28; Cashman Class action law and practice (2007) 7 .

9 In Phillips Petroleum Co v Shutts 472 US 797 (1985) 810 the court phrased it thus: 'He may sit back and allow the litigation to run its course, content in knowing that there are safeguards provided for his protection.'

10 See eg Murphy and Cameron 'Access to justice and the evolution of class action litigation in Australia' 2006 Melbourne University Law Review 399 419; P Dawson Nominees Pty Ltd v Multiplex Ltd [2007] FCA 1061 par 48; Freer Introduction to civil procedure (2006) 696.

11 See Mulheron supra $n 5$ at 384.

12 Freer supra n 10 at 731. 
than by description as in the case of opt outs). Failure to respond to the notice given to potential claimants/plaintiffs alerting them to the proceedings would exclude an individual claimant/plaintiff from the class, and such individual would be unable to share in any benefit derived from the litigation.

To trace the origin of the opt-out model, one has to go back in history. It is trite that the class action has its ancient roots in the Supreme Court of Judicature Act, 1873 in England and the fusion of common law and equity $^{13}$ from where it was imported, reinterpreted and developed in America through Equity Rule $38^{14}$ in particular before spreading to other jurisdictions. When Federal Rule 23 became part of the original Federal Rules of Civil Procedure of $1938,{ }^{15}$ it distinguished between three types of class actions of which the third (created to accommodate permissive joinder among diverse members who shared a common interest), ${ }^{16}$ required their consent for litigation purposes in the form of an opt-in mechanism. ${ }^{17}$ When the present Rule 23 of the Federal Rules of Civil Procedure $^{18}$ was cast in its present mould in 1966, Federal Rule 23(b)(3) not only acquired two additional requirements that had to be fulfilled, ${ }^{19}$ but seemingly in order to alleviate concerns regarding due process, ${ }^{20}$ the

$1336 \& 37$ Vict c 66 (UK). See in general the seminal work by Yeazel From medieval group litigation to the modern class action (1987).

14 Yeazell supra $\mathrm{n} 13$ at 225 . This was in fact the renumbered Rule 48 which stated that absentee class members were not bound by a judgment: James Hazard Leubsdorf Civil Procedure (2001) 648. Cassels and Jones The law of large-scale claims. Product liability, mass torts, and complex litigation in Canada (2005) 324 acknowledge that although the American class action provided an example for the Canadian legislature to follow, Canadian mass tort law owes ‘at least as much' to English jurisprudence.

15 Kaplan 'Continuing work of the Civil Committee: 1966 amendments of the Federal Rules of Civil Procedure (1)' (1967-68) Harvard Law Review 356 376-377.

16 Hazard Gedid Sowle 'An historical analysis of the binding effect of class suits' (1997-98) University of Pennsylvania Law Review 1849 1937-1938.

17 Hazard Gedid Sowle supra n 16 at 1938, and they remark that this category was a 'permissive joinder device' rather than a class action according to then commentators.

18383 US 1029 (1966) (hereafter FR).

19 The 'basic' requirements for all class actions (numerosity, commonality, typicality and adequacy) contained in FR 23(a) are well known. FR 23(b)(c) in addition requires predominance and superiority. As the other types of class actions (FR 23(b)(1)(A); 23(b)(1)(B) and 23(b)(2)) do not expressly provide for opt-out, they are not considered. See in general Kaplan supra $\mathrm{n}$ 15 at 390 .

20 Kaplan supra n 15 at 377 391-394 states this as a fact, but Williams 'Due process class action opt outs, and the right not to sue' 2015 Columbia Law Review 599607 points out that an Advisory Committee note which explains the 1966 amendments 'suggested a possible link' between due process and the opt-out right. He also points out that certain early courts held that due process required said notice and opt-out right in particular class actions, while others held that such a right was 'solely a creation of Rule 23 itself' and not a Constitutional requirement. However, it is submitted that the recent cases of $A T \&$ \& Mobility LLC v Concepción $131 \mathrm{~S}$ Ct 1740 (2011) and Wal-Mart Stores Inc v Dukes 131 S Ct 2541 (2011) which favoured the dueprocess-based opt-out-right view first espoused in Phillips Petroleum $v$ 
rule makers included notice to absent members and opt-out rights for them.

Although Federal Rule 23 creates three different types of class actions, notice to class members is mandatory only for a class action for damages under Federal Rule 23 (b) (3) 21 and discretionary for Federal Rule 23(b)(1) and (b)(2) class actions ${ }^{22}$ in which instances damages are not sought. There is also no automatic right of opt out in relation to these two categories, although the courts have on occasion relied on the wide discretion afforded by Federal Rule $23(d)(2)$ to allow members to opt out. ${ }^{23}$ Notice in the Federal Rule 23(b)(3) category is particularly onerous, as individual notice is required ${ }^{24}$ where members 'can be identified through reasonable effort', while the others must receive the 'best notice practicable under the circumstances'. The dire results of this requirement are amply illustrated by the protracted litigation and culminating in the well-known Eisen $v$ Carlisle \& Jacquelin. ${ }^{25}$

Although most common law jurisdictions favour the opt-out class action (with Britain being the notable exception), ${ }^{26}$ notice to potential class members is not necessarily mandatory and the courts are generally speaking, given a wide discretion regarding the type of notice (individual or not) where required.

Shutts supra, seem to suggest a settled Supreme Court view in this regard. As to due process generally, see Wasserman Procedural due process $A$ reference guide to the United States Constitution (2004).

21 See FR 23(C)(2)(B).

22 FR 23(c)(2)(A). See also Freer supra n 10 at 730.

23 The rule provides: 'In the conduct of actions to which this rule applies the court may make the appropriate orders: [...]

(2) requiring, for the protection of the members of the class or otherwise for the fair conduct of the action, that notice be given in such manner as the court may direct to some or all of the members of any step in the action ....

24 See Federal Judicial Centre Manual for Complex Litigation (1995) par 30.211.

25417 US 156 (1974). In this matter the court held that the expense of notice was to be borne by the class representative. The mailing of individual notices to well over three million members proved to be hugely expensive.

26 And probably set to remain 'conservative': Hodges 'From class actions to collective redress: a revolution in approach to compensation' 2009 Civil Justice Quaterly 41 66. Unsurprisingly Scottish Law Commission (Scot Law Com No 154) Multi-Party Actions (July 1996) par 4.55 recommended that 'group members must elect to be members of the group'. The trend in the European Union is also to favour the opt-in class: see in general Hodges The reform of class and representative actions in European Legal Systems: a new framework for collective redress in Europe (2008); Hodges "Collective redress in Europe: the new model' 2010 Civil Justice Quaterly 370. The Netherlands is an interesting exception in the EU: although the procedure is not a class action in the usual sense but rather a collective settlement mechanism under the Wet Collectieve Afwikkeling Massaschade (WICAM), victims who are not in agreement with the settlement agreement have the option to opt out on notice within three months: see Dutch Civil Code art 7:908 par 2. See in general Hurter 'Class action developments in the Netherlands' 2012 SAPL 178. 
In Canada, Ontario ${ }^{27}$ led the way with the other provinces fairly rapidly following. ${ }^{28}$ In Ontario a notice is mandated by statute, but the court, after considering matters such as the cost of the notice; the size of the claims; the number of class members and where they are located, may decide that dispensing with the notice to class members is warranted. $^{29}$ The notice is also mandated by legislation in British Columbia, and the provisions are similar to that of Ontario. ${ }^{30}$ In both instances judicial approval of the notice is required and the content must clearly set out matters such as a description of the proceedings and the relief sought; the opt out date; the size of the individual claims; the number of class members; the financial consequences of any agreement regarding fees and disbursements, etcetera. ${ }^{31}$ The clear aim of the provisions is to ensure that the notice is clearly drafted and understandable to laypersons. No specific type of notice is mandated, and therefore it is reasonable to assume that the courts will use their discretion based on the facts of each case to prescribe the type that would ensure effective notice. Methods that are used include posting; advertising; publishing; leafleting ${ }^{32}$ and internet sites. ${ }^{33}$

In Australia Part IVA of the Federal Court of Australia Act 1976 (Cth) ${ }^{34}$ introduced the opt-out model in $1992^{35}$ and notice to class members is mandatory, except where the action does not involve a claim for damages. ${ }^{36}$ The best possible notice to class members is required, and the court has a wide discretion to determine the type of notice, which may include press advertisements, and radio and television broadcasts. ${ }^{37}$

27 See Class Proceedings Act SO 1992 c6. As the legislation of the other provinces has by and large been modeled on that of Ontario, reference will mostly to be to the Ontario Act and the British Columbia Act where necessary. As explained by the Alberta Law Reform Institute Class Actions Final Report No 85 (December 2000) 98 'e. ....an 'opt out' system is the normal choice in Canada. We view harmony with the law in other Canadian jurisdictions and the discouragement of forum shopping as important.'

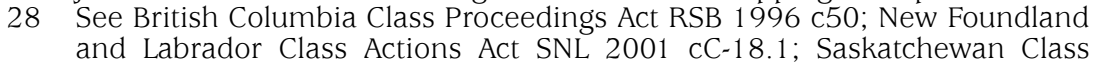
Actions Act SS 2001 cC-12.01; Manitoba Class Proceedings Act CCSM 2003 c130; Alberta Class Proceedings Act SA 2003 cC-16.5; New Brunswick Class Proceedings Act SNB 2006 CC-5.15. The Rules for regulating the practice and Procedure in the Federal Court of Appeal and the Federal Court, Pt 4 ss 299.1 - 299.42 'Class Actions' must be read in conjunction with the applicable legislation.

29 Idem s 17(1)-(3); s 18(1); s 29(4).

30 Idem s 19(1)-(3); s 20(1); s 21(1); s 35(5).

31 Idem s 17 (6); s 20 Class Proceedings Act (Ont) and s 19(6); s 22 Class Proceedings Act (BC).

32 Idem s 17(4)(b) Class Proceedings Act (Ont); s 19(4)(c) Class Proceedings Act (BC).

33 Idem s 19(4)(e) Class Proceedings Act (Man).

34 Idem s 33E; s 33H; s 33J.

35 See Federal Court of Australia Amendment Act 1991 (Cth).

36 Idem s 33X(1)-(2).

37 Idem s 33Y. 
Finally, the British Group Litigation Order (GLO) continues the tradition of employing opt in mechanisms, and has withstood criticism and calls for change as well as review. ${ }^{38}$ As already indicated, the GLO is neither a class action, nor a representative action, but is in fact a case management tool under the Civil Procedure Rules: ${ }^{39}$ a court may make such an Order for the "case management of claims that give rise to common or related issues of fact or law' ${ }^{40}$ In effect individual cases that have already been instituted ${ }^{41}$ are grouped together and court managed, causing the GLO to be described as no more than a 'permissive joinder device'. ${ }^{42}$ Litigants wishing to form part of the group have to take an affirmative action to litigate by being entered onto the group register.

\section{The Opt-in or Opt-out Choice Dilemma}

A discussion regarding this aspect cannot be divorced from certain fundamentals regarding the origins of the class action and of civil procedure. These matters informed not only the original design of the device, but continue to play a role in subsequent developments and certainly direct most of the arguments for or against the opt-in/opt-out choice.

\section{Principles and Policy}

One of the main values of the adversarial system of civil procedure adhered to in common law jurisdictions, is that of litigant autonomy: through the features of party presentation and party prosecution, the ultimate control over what is submitted to a judge for decision vests in the litigants. And, since it is a litigant who independently (individually)

38 See eg Lord Woolf Access to justice: Final report to the Lord Chancellor on the Civil Justice System in England and Wales (1996); Mulheron 'Some difficulties with Group Litigation Orders - and why a class action is superior' 2005 Civil Justice Quaterly 40; Mulheron 'Justice enhanced: framing an opt out class action for England' 2007 Modern Law Review 550; Mulheron supra n 5 at 376.

39 See rule 19.10 and Zuckerman Zuckerman on civil procedure (2013) para 13.103. It was apparently introduced on the 'assumption' that opt out representative actions did not exist in England: see Sorabji 'The hidden class action in English civil procedure' 20094 CJO 498512 who argues that that assumption fails to 'take account of the true nature of the representative rule, which ... in some circumstances is a mandatory class action'.

40 Commonly referred to as the 'GLO issues'. After such issues have been identified, rule 19.11(2)(a) requires that a register of group claims be established. A management court will oversee the claims and manage the proceedings. It is important to note that any judgment or order that is given on a GLO issue binds all parties on the group register or which are subsequently entered onto the register (rule 19.12). See in general on the GLO, Zuckerman supran 39 at 676-692.

41 Or been 'issued' as referred to in the Civil Procedure Rules and Practice Direction.

42 Andrews 'Multi-party proceedings in England' 2001 Duke Journal of Comparative and International Law 249262. 
chooses to either institute or defend an action, it is clear that civil litigation is voluntary, ${ }^{43}$ and that a litigant is the master of the litigation.

Arguments in favour of the retention of the opt-in mechanism which existed in the original Federal Rules of Civil Procedure of 1938 (discussed above), were largely based on litigant autonomy and featured strongly in presentations to the Advisory Committee on Civil Rules. However, this option was rejected, as its consequences were viewed as lacking moral justification due to the fact that it would effectively lead to the 'freezing out ${ }^{44}$ of particularly small people with small claims who, for reasons such as ignorance, timidity and unfamiliarity with business or legal matters, will simply not take the affirmative step of opting in. A possible reason why litigation autonomy assumes such importance in America is that it is viewed as one of their 'deeply held' social values, namely to have one's say, and more particularly, to have one's 'day in court'. ${ }^{45}$ This, in turn, is linked to their constitutional guarantee regarding due process that might be interpreted to create a 'right' to a 'day in court'. 46

Although these particular concerns and the American class action developments have not formed part of the background of class action development in other common law jurisdictions, ${ }^{47}$ the debate for or against the opt-out mechanism has nevertheless been held along similar lines, as will be seen below.

\section{The Basis for the Choice}

The difference between the opt-out and the opt-in mechanism is easily comprehended, but it is the particular choice of mechanism that is problematic. The choice is not simply based on considerations of

43 It has also been argued that even if civil procedural law's only purpose is to supply civilization with a substitute for vengeance, the starting point for the law that provides the institutions and regulates the litigation process to achieve this, is the voluntary nature of civil litigation: see Jolowicz On civil procedure (2000) 77.

44 Kaplan supra n 15 at 397-398.

45 See James Hazard \& Leubsdorf supra n 14 at 383. The other two social values highlighted are open opportunity (to be a judge or lawyer or to participate as citizen) and having checks and balances to limit the power of all participants in civil litigation.

46 Jones Theory of class actions (2003) 6; Williams supra n 20 at 603 614-615; Moller 'The checks and balances of forum shopping' 2012 Stanford Journal of Complex Litigation 107157.

47 See eg Jones supra n 46 at 5-6 stating that ' $[\mathrm{t}$ ] he Canadian constitutional system does not offer any of the impediments experienced in the United States: there is no constitutional right to a jury trial, no civil 'property' or 'due process' guarantee that might be interpreted so as to preserve a 'right' to the 'day in court'. In Britain the principle of party autonomy is still very much in evidence despite the so-called New Culture which is governed by the Overriding Principle introduced by the Woolf reforms and captured in CPR rule 1.1. See in general Andrews Andrews on civil procedure Vol 1 (2013) par 1.11; Jacob Civil litigation. Practice and procedure in a shifting culture (2001) 38-39. 
convenience, and the decision requires the balancing of complex issues as discussed later. ${ }^{48}$

A discussion of each mechanism cannot completely be divorced from the arguments for and against each one, and, while it is not the focus of the present discussion, some will thus necessarily form part of the discussion of each mechanism where appropriate.

\section{The Opt-in Mechanism}

This may be a 'true' opt-in procedure, or an opt-out procedure which in effect requires members to 'opt in' by filing proof of claim after certification (in whatever form is required) as a prerequisite to obtain relief in a successful action. ${ }^{49}$ (In the latter instance serious consequences attach to a failure to respond). ${ }^{50}$ For purposes of this discussion the latter procedure is not considered further, as it serves an efficacious purpose at that point, and does not serve to define the initial class.

At the heart of this mechanism lies the principle of individual autonomy, and much of the arguments in defence thereof is aimed at its preservation, that is, to ensure that an individual participates in litigation only by own choice. ${ }^{51}$ Freedom of choice satisfies the principle that a person's legal rights should not be determined without his or her express consent, and it is argued that the act of opting in ensures that consent is "no longer implied or fictitious' 52 (obviously due to the individual's conscious action). Many commentators are very vocal in their criticism of the opt-out mechanism on this point, because by not unequivocally expressing their consent to litigation, absent class members are seen to be giving up their rights to individual litigation. Accordingly, the low optout rates ${ }^{53}$ are viewed as indicative of the fact that most class members, for whatever reason, will not opt out - whether or not they want to

48 See eg Ryan 'The development of representative proceedings in the Federal Court' 1993 Australian Bar Review 131137 referring to the commencement of class actions without the consent of the absent class members as 'controversial'.

49 As in the case of various matters in America under FR 23(b)(c). See also Legg 'Reconciling litigation funding and the opt out group definition in Federal Court of Australia class actions - the need for a legislative common fund approach' 2011 Civil Justice Quaterly 5255.

50 Such a member will not be able to obtain his or her share of any monetary award, but moreover will also be prevented from commencing his or her own action against the defendant.

51 This view is not confined to the American debate: see eg Scottish Law Commission (Scot Law Comm No 154) Multi-party actions (July 1996) par 4.54 and recommendation 4.55 .

52 See Bassett 'US class actions go global: transnational class actions and personal jurisdiction' 2003 Fordham Law Review 4189.

53 This refers to the number of class members who exercise their right to opt out, either because they are not interested in pursuing litigation, or wish to litigate independently. It is well known that these rates are low: see eg Carvana and Morabito 'Australian unions - the unknown class action 
remain in the class. For this reason, the opt-out mechanism is referred to as a 'poor proxy for consent' and the consent is termed 'fictitious'. 54 Bassett ${ }^{55}$ takes further issue with the view that a member's failure to opt out constitutes consent to the court's personal jurisdiction, and argues that this silence on the part of the member should rather be interpreted, not as consent, but as confusion. Nevertheless, the view is held that true consent is ensured only in opt-in classes, and that the rights of absent members to individual litigation are thus protected. ${ }^{56}$

The opt-in procedure allows the class members to be individually identified as each member has to take a prescribed step ${ }^{57}$ in order to join the action. At the same time, the number of class members is thus easily determined. Therefore, not only is the class precisely determined ${ }^{58}$ (making certification easier), but also the class size. However, this procedure has a significant consequence: a much reduced class size (compared to opt-out procedures). ${ }^{59}$ Although it was argued before the Ontario Law Reform Commission that the low take-up rate is due to disinterest in the claims, it was also suggested that the failure arose from various reasons other than lack of interest, such as social and psychological barriers; fear of involvement in the legal process; illfounded concerns over legal costs; fear of legal sanctions from employers and others in a position to take reprisals, and simply the demands of everyday life. 60

Nevertheless, proponents of this particular mechanism, apart from stressing the benefit regarding autonomy and class ascertainability, argue that the reduced size of the class allows for an easier ascertainment of damages, and prepares the defendant(s) for the extent of any potential liability (in other words, the size of the pool of potential claimants). ${ }^{61}$ However, it should be noted that ease of ascertainability does not bring with it anonymity, and this may dissuade opt ins in circumstances where

protagonists' 2011 Civil Justice Quarterly 382 398; Cottreau 'The due process right to opt out of class actions' 1998 New York University Law Review 480 481; Hodges supra n 26 at 121; Mulheron 2007 MLR supra n 38 at 557; Lahav 'Are class actions unconstitutional?' 2011 Michigan Law Review 993 1005-1006; Dodson supra n 4 at 200.

54 Bassett supra $\mathrm{n} 52$ at 89.

55 'Class action silence' 2014 Boston University Law Review 17811783.

56 Bassett supra $\mathrm{n} 52$ at 89.

57 It may entail entering their particulars on a group register, but it may also entail the commencement of individual actions which are then grouped together and case managed as in the case of the British GLO - see in general Andrews supra n 47 par 22.45 - 22.46.

58 Or 'ascertainable' as required in a seemingly growing number of federal court decisions (despite not being specifically required under Federal Rule 23): see Shaw 'Class ascertainability' 2015 Yale Law Journal 23542357.

59 See eg Ontario Law Reform Commission Report on class actions (1982) Vol II 131; 482-483 (hereafter Ontario LRC Report).

60 Ontario LRC Report supra n 59 Vol I 132. See also Hodges supra n 26 at 120.

61 The Law Reform Commission of Hong Kong Class actions (May 2012) par 4.5; Ontario LRC Report supra n 59 Vol II 48. 
there are ongoing relationships (as referred to above) and there is fear of reprisals.

The opponents are quick to point out a number of deficiencies in this option. Individual autonomy may be rendered meaningless to an individual if in a class action his or her identity is not initially known. If notification that an opt-in act is required does not reach these individuals, they are effectively denied an opportunity to indicate their interest in the case. Also, even if notification reaches them, it will not necessarily ensure action on their part. The Ontario Law Reform Commission pointed out that the 'same social and psychological factors that discourage persons from bringing their own civil actions will prevent them from taking other forms of affirmative action'. ${ }^{62}$ Referring to an American study, it also pointed out that despite 'a generally high level of education' many putative members also did not understand the messages contained in the notices with respect to their consumer rights in the action. ${ }^{63}$ This clearly indicates that an almost automatic assumption that the level of education is a determining factor in the choice of a mechanism is risky - it would thus seem that even if a notice reaches the target group, it does not mean that the significance of the notice will be understood or that the content will not pose problems for its understanding, or not cause uncertainty. Clearly this aspect raises serious concerns regarding access to justice.

In similar vein, Hodges ${ }^{64}$ warns that where many individuals may not know of their right to claim or of the arrangements, this may result in a situation where an insufficient number of them opt-in and participate in any judgment. Not only do under-inclusive classes not secure access to justice for all who fall within the class definition, but they neither ensure that the size of the class accurately reflects the group that has been harmed in order to establish an appropriate sanction for the harm caused, nor do they provide class closure for the defendant, ${ }^{65}$ causing uncertainty regarding numbers of members who may litigate independently. ${ }^{66}$

As far as the establishing of potential claims by the defendant is concerned, the matter may also not be so clear-cut. Proponents seem to lose sight of the fact that a defendant will, in any event, not be able to

\section{Ontario LRC Report supra n 59 Vol II at 480}

63 In America the problems related to badly drafted notices and general legalese were recognised, and FR 23(C)(2)(B) now requires that a notice state 'concisely and clearly' the required contents in 'plain, easily understood language'. Freer supra n 10 at 732-733 quote a few 'telling responses' to a class action notice collected by Prof Miller in a matter involving allegations of over-charging for antibiotics, one being: 'Dear Sir: I received your pamphlet on drugs, which I think will be of great value in the future. I am unable to attend your class, however.'

64 Supra $\mathrm{n} 26$ at 120.

65 Closure refers to the cut-off date for making claims to achieve finality. See in general Mulheron supra $\mathrm{n} 5$ at 376.

66 Walker 'Are national class actions constitutional? A reply to Hogg and McKee’ 2010 Osgoode Hall Law Journal 95137. 
completely accurately estimate his or her ultimate liability for the simple reason that the defendant cannot know the number of individual actions that may be brought before the advent of the expiry date of the limitation (prescription) period for claims. Furthermore, although it may be assumed that a large number of members who have opted in will pursue their claims, it is conceivable that some will not for various reasons (such as loss of interest).

Finally, the Ontario Law Reform Commission expressed the opinion that a 'true' opt-in procedure would result in the creation of a procedure which is not a class action, but would in fact amount to a "permissive joinder device, 67 as it obliges each class member to join the action after certification.

\section{The Opt-out Mechanism}

In terms of this mechanism, individuals become members of a particular class without having had a prior relationship with the representative plaintiff (and his or her lawyer), and a class action may be commenced without their (the so-called absent members, ${ }^{68}$ ) express consent. As a consequence, opt-out classes are generally more inclusive than opt-in classes, which translate into greater numbers of members. ${ }^{69}$ These typically larger class numbers of opt-out classes are viewed as a positive, because if viewed against the background of the objectives of the class action device, the so-called economies of scale are greater, making claims of small value better viable and preventing multiplicity of actions. Individual litigation is a costly affair and considerable benefit is achieved when any number of claims sharing common issues are adjudicated simultaneously instead of individually - both in respect of the individual and in respect of judicial resources. ${ }^{70}$ Duplication of litigation so avoided lessens the burden on court resources, ${ }^{71}$ and also avoids the possibility of inconsistent determinations of the same issue in different proceedings. Other 'knock-on judicial economies' such as the bringing about of early settlement, may also ensue. ${ }^{72}$ These classes are also seen

67 Ontario LRC Report supra n 59 Vol II at 483.

68 The term 'absent class members' refers to class members who did not commence the action.

69 This fact is undisputed by all commentators. Recent studies in American literature in particular have indicated that almost $99 \%$ of class members take up the default position: Eisenberg and Miller 'The role of opt-outs and objectors in class action litigation: theoretical and empirical issues' 2004 Vanderbilt Law Review 1529. See also Lahav supra n 53 at 1005 and Cottreau supra n 53 at 481 n10. For a comparable position in Australia, see Carvana and Morabito supra n 53 at 397-398.

70 See eg Williams supra n 20 at 616-617; Ontario LRC Report supra n 59 Vol II at 487 .

71 Mulheron supra n 8 at 59 points out that not every class action will promote judicial efficiency, and later (239-245) discusses this in terms of the "no need' (for a class action) argument with relation to whether a class action is the superior device for obtaining large-scale relief.

72 Mulheron supra $\mathrm{n} 8$ at 60 . It is also pointed out that the vast majority of class actions (like other civil matters) settle before trial. 
as levellers of the litigation playing field when individuals face large, powerful and well-financed defendants. ${ }^{73}$

The right of class members to exclude themselves from a class action by taking an affirmative step and 'opt out' is a valuable right, as it enables members to commence their individual actions (thus preserving the dayin-court ideal) and to escape being bound by a judgment that is adverse to the class. Opt-out rights, therefore, have a dual function: they may signify consent ${ }^{74}$ to jurisdiction (and acceptance to being bound by a subsequent judgment of the court), and they also provide the procedural protection of a class member's right to pursue an individual action, or not to pursue it. ${ }^{75}$ (It may even be argued that this right also comes to the assistance of those members who simply are not interested in pursuing any action at all, thus putting paid to the argument that the opt-out regime obliges class action members to sue the defendant). ${ }^{76}$

The required notice to the class must take a form that will adequately inform them, not only of the proceedings, but also of the consequences of their involvement. Notice, thus, guarantees due process and provides a reasonable opportunity for class members to exclude themselves from the class. ${ }^{77}$

The opt-out mechanism therefore not only provides a measure of individuality for a class member, but it also provides finality for both the class member and the defendant: once excluded, the class member either has to 'go it alone', or give up on litigation, giving the defendant the opportunity to prepare to meet the potential maximum number of further (individual) actions, based on the opt-out number. Finality for the defendant of course also lies in the fact that the judgment binds all class members who have not opted out, regardless of outcome. Bearing in mind the general low opt-out rate, it is submitted that this holds a considerable benefit for defendants (especially corporates who could be facing multiple consumer claims).

73 Williams supra n 20 at 616-617; Legg supra n 49 at 62.

74 See eg Bone 'The puzzling idea of adjudicative representation: lessons for aggregate litigation and class actions' 2011 George Washington Law Review 577592 referring to 'inferred consent' and Phillips Petroleum Co v Shutts supra at 892-893.

75 Thus protecting the 'day in court' ideal as class members' claims are not extinguished in the class proceeding. It has been argued that this right protects an individual's ability to decide whether his or her claim will be litigated: Cottreau supra $n 53$ at 488-659.

76 Williams supra $n 20$ at 659 argues that opt-out rights preserves an individual's ability to decide whether or not his or her claim will see the inside of a court at all.

77 The effectiveness of such notices is debatable: the language in which notices are drafted may render them incomprehensible to the lay reader: Cottreau supra n 53 at 481 . 


\section{Policy Considerations}

Law develops within a particular social context. This is clearly illustrated by Yeazell's ${ }^{78}$ description of the social background to the origin of the 1966-version of the American class action. It was the recognition of the existence of many access-to-justice problems that gave rise to the modern class action, ${ }^{79}$ and subsequent developments illustrate that the class action device can be a powerful device to facilitate socio-legal change.

However, the class action is an anomaly within the context of traditional Anglo-American procedural law. The much-revered principle of party autonomy (or individualism) is not a comfortable fit with the class action device, as illustrated by the tension created between this principle and collectivity in group litigation. Essentially, a class action allows an individual to institute and conduct legal proceedings - not only on his or her behalf, but also on behalf of other individuals without their express consent, while the only connection is shared common issues after suffering injury caused by the same defendant. And to compound matters, the objective is to obtain a single determination of these issues through a judgment that is binding on all class members (including the absentees). The effect thereof is that individual claims are destroyed, and the ideal of the 'day-in-court' is not preserved, causing some commentators to reject the device while others have defended it as 'the most useful remedy in history'. 80

Although the anomaly is not easily explained or justified, it is at the core of the debate regarding the highly controversial issue whether the binding effect on class members should be achieved through an opt-in or an opt-out mechanism. It is at this point where the principle of party autonomy (often encountered as the insistence on an individual's right to a 'day in court') is used as an argument in favour of either the opt-in or the opt-out mechanism as seen from part 3 above. Unfortunately, the endless listing of pros and cons by either side in the debate in the literature and before various law reform commissions, as well as the mere weighing of mechanism attributes have (it is submitted) also contributed relatively little towards reaching a definitive answer. While

78 See Yeazell supra n 13 at 239-245 and 31 above, describing the social background made up of racial politics and the failure of market capitalism that shaped the 1966 revision of the Rule 23 of the Federal Rules of Civil Procedure in the US.

79 See Mulheron supra n 8 at 52 where she notes that access to justice has been described as the 'cornerstone of class proceedings'. See also Davis 'Towards the proper role for mass tort class actions' 1988 Oregon Law Review 157169.

80 See Pomerantz 'New developments in class actions - has their death knell been sounded?' 1970 Business Law 1259 1259. See also Handler 'The shift form substantive to procedural innovation in antitrust suits' 1971 Columbia Law Review 19 calling it 'legalised blackmail' and Miller 'Of Frankenstein monsters and shining knights: myth, reality and the "class action problem”. 1979 Harvard Law Review 664 for a more positive view. 
these actions are not considered unimportant (as they certainly highlight the complexities that accompany the choice), they obscure the fact that the choice lies in the balance of fundamental legal principles and rights and values.

What has become clear from these debates is that arguments amounting to the valuation of fundamental legal rights above all else point towards a restrictive approach and towards choosing an opt-in mechanism, while considerations of justice for the plaintiffs (and thus an independent good) point towards adopting an opt-out mechanism and a less restrictive approach. As many proponents of opt-in are usually also opposed to the class action device, it is possibly safe to deduce that their insistence on adhering to individualism and all it entails is, in fact, a way of expressing their opposition to this device. The reasons for such opposition are varied, but could probably be encapsulated in the suggestion that it is because of the class action's 'potential ... to upset the status quo' in a legal system. ${ }^{81}$ If this is indeed a correct deduction, then one should be very careful in selecting a mechanism, especially where the class action device has already been accepted in a system. What should then be borne in mind is that opt-in regimes do not promote inclusivity, and an under-inclusive class does not ensure access to justice for all the individuals who fall within the class definition, but only for those opting in. As a result the group that suffered harm is not reflected accurately, and a class action in such instance is prevented from achieving its stated objectives.

It has long been recognised that class actions aim to achieve three major goals, ${ }^{82}$ the first being 'judicial economy'. This goal is seen to be achieved by having issues that are common to a group determined in a single action, thus saving costs, ensuring efficiency of process and avoiding conflicting judgments in individually commenced actions. A second goal is increased access to justice in facilitating access to courts by enabling individuals with non-recoverable claims ${ }^{83}$ or whose claims would not have been brought due to social or psychological barriers to litigate. The third goal is behaviour modification to deter wrongful

81 Morabito 'Class actions: the right to opt out under Part IVA of the Federal Court of Australia Act 1976 (Cth)' 1994 Melbourne University Law Review 615628 .

82 See Ontario LRC Report supra n 59 at 140-146; Cassels and Jones supra n 14 at 336. However, the objective of deterrence has not unanimously been accepted across all common law jurisdictions: in Australia the ALRC Report (Australian Law Reform Commission Grouped proceedings in the Federal Court Report No 46 (1988)) par 67; 323; 354 did not accept it as a goal. Some Australian commentators do, however: see Morabito supra n 81 at 627-628, as well as Alberta Law Reform Institute Report supra n 21 at 9.

83 These refer to claims of which the individual litigation costs would be greater than the expected amount of recovery (but would justify the lesser expense required to obtain a share of a class action judgment). This term has been taken from Note 'Developments in the law - class actions' 1976 Harvard Law Review 13181325 1356. Based on this work, claims are often divided into three categories: individually recoverable, individually not recoverable and 'non-viable': see eg Ontario LRC Report supra n 59 at 116. 
behaviour on the part of defendants where such behaviour may affect large numbers of individuals. Furthermore, the strict adherence to the principle of individualism presupposes equal litigative power for all individuals, but loses sight of the reality of socially and economically disenfranchised individuals in modern society.

The low take-up rate in respect of opt ins should, further, be counterindicative to choosing this mechanism, especially in societies where potential groups are more vulnerable due to social and economic barriers and where illiteracy, distrust or fear of the legal system and ignorance regarding personal rights are not uncommon. To address socio-economic exclusion and imbalances, a mechanism which provides for the greatest possible inclusion should be favoured to ensure that the vulnerable are 'swept in'.84

As already stated, in designing a class action regime the choice of mechanism is, in essence, one of policy to determine the question surrounding the participation in litigation by an individual and the determination of his or her rights without his or her express consent. South Africa still has to establish its own class action policy in this regard. Although the American influence on class action jurisprudence worldwide is unmistakable, it is suggested that it bears pointing out that there was no wholesale introduction of the American class action (including its procedural baggage and doctrinal eccentricities) by the other common law jurisdictions, and that their class action developments bear the stamp of their own unique legal culture with a clear emphasis on access to justice values. ${ }^{85}$ In particular there is an absence of the dominant consideration of due process, ${ }^{86}$ and the consequent almost myopic focus ${ }^{87}$ on the day-in-court ideal which directs much of the American bimodal mechanism debate. Although the prominent attention to this issue in America is constitutional ${ }^{88}$ and thus relevant for South African developments (due to section 34 of the Constitution ${ }^{89}$ that provides that 'everyone' has the 'right to have any dispute ... decided ... before a court ...'), this does not mean that this section should be interpreted in a manner that leads to an over-statement of a litigant's choice not to surrender his or her claim to the group. It should instead be

84 See Alberta Law Reform Institute Report supra n 27 at 98 where in the principal recommendation agreement is expressed with the Ontario LRC Report supra $\mathrm{n} 59$ on the choice of regime, and it is stated with approval that the 'vulnerable should be swept in'.

85 American doctrine is contained in their Constitution (see above), while the English approach stems from the common law. The Canadian and Australian approach, while acknowledging the common law principles, followed a more pragmatic legislative route and access to justice values: see Jones supra n 46 at 2; Williams supra n 20 at 5-15; Cashman supra n 8 at 26-28.

86 See eg Williams supra n 20 at 44; Cottreau supra n 53 at 480 et seq.

87 Williams supra n 20 at 603.

88 Galligan Due process and fair procedures A study of administrative procedures (1996) 187-194.

89 The Constitution of the Republic of South Africa, 1996. 
interpreted as a right of access to justice, in terms of which the legal system provides a mechanism to allow, from the point of view of public policy, that a class be defined as broadly as possible to either benefit (depending on whether the action is successful) or bind (even if unsuccessful), the greatest number of class members. In order to implement this suggested policy the local approach need not be dogmatic, for although common law jurisdictions have steadfastly incorporated the opt-out mechanism into their class action regimes, a number of 'varying approaches' 90 (models) have been identified, raising the possibility of a more flexible approach than the strictly bimodal approach discussed above.

One such an approach, although the option has so far never been enacted, is to leave the opt-in or opt-out decision entirely to the court, as was recommended by the South African Law Commission. ${ }^{91}$ However, this proposal has not received unequivocal support from law reform commissions, and the Alberta Law Reform Institute was particularly critical of this choice, due to the host of uncertainties that may conceivably be created by such judicial choice. ${ }^{92}$ Their criticism mainly focussed on the fact that parties would be:

(1) placed in an uncertain position regarding their case preparation, because they would have no advance knowledge which procedure would be followed;

(2) that expensive litigation over the procedural choice made by the court could ensue; and,

(3) finally, on the difference in limitation (prescription) periods - as under the opt-in scheme time stops only once a plaintiff files his or her request, while for an opt-out scheme time is suspended when the class action is filed.

The argument against judicial choice is persuasive, and the recommendation of the South African Law Commission can accordingly not be supported. It can also be questioned whether a model which includes an opt in should in any event be considered, as it bears repeating that an opt-in regime has rightly been viewed by various American commentators and law commissions (such as the Ontario Law Reform Commission) as a 'permissive joinder device', and not as a class action at all. Moreover, purely on access-to-justice considerations, it is a difficult regime to defend - in recommending the adoption of the opt-out regime, the Alberta Law Reform Institute went so far as to state that an opt-in requirement would be 'fundamentally inconsistent with the access

90 Mulheron supra $\mathrm{n} 8$ at 29-34.

91 South African Law Commission The recognition of class actions and public interest actions in South African law (Project No 88) (1998) par 5.11.4.

92 See supra n 27 at 98-99; 241-242. See also Mulheron supra $n 5$ at 394. 
to justice rationale endorsed as a basic justification for expanded class proceedings legislation'. 93

Against this background certain pertinent aspects of the recent decision in Nkala and others $v$ Harmony Gold Mining Co Ltd and others ${ }^{94}$ are briefly considered to establish whether the case provides some indication of the direction future developments may take and if it lends some support for the expansive approach advocated above. In this matter the court considered an application for the certification of an action comprising two separate and distinct classes on behalf of current and past mineworkers who contracted silicosis or TB while in the employ of various gold mines as a class action. Of relevance to the present discussion are two matters. In the first instance the court in no uncertain terms expressed its commitment to support a litigant's constitutional right of access to court, ${ }^{95}$ and held that the class action in this matter was the 'only realistic option' through which the mineworkers could realise this right in view of their dire personal circumstances. ${ }^{96}$ This view clearly does not indicate a leaning towards strict adherence to the principle of individualism. Secondly, the court adopted a so-called bifurcated process involving two stages in which it directed the members of the two classes to opt out of the proceedings ${ }^{97}$ if they did not wish to be bound by the judgment or judgments in the first stage, and to opt in during the second stage. It was envisaged that the issues common to all the mineworkers would be decided in the first stage, ${ }^{98}$ whereas the individual issues is to be dealt with in the second. ${ }^{99}$ It was made clear that those who did not opt out during the first stage would be bound by the findings of the court during this stage. Should the mineworkers be successful during this stage, then only would the opportunity to opt in arise. ${ }^{100}$ It is contended that, despite the terminology used and statements that mineworkers may wish to take advantage of 'both the opt-in and opt-out options' and that this process affords them the 'widest choice possible', ${ }^{101}$ the court did in fact not adopt the 'judicial choice'-model, but the opt-out model, albeit in hybridised form. ${ }^{102}$

93 See supra $\mathrm{n} 27$ at 98 . See also Part 3 where the concern was discussed that many potential class members who fail to opt in due to ignorance or because of social exclusion would be deprived of the benefits of the class action - precisely those in most need thereof.

94 See supra n6.

95 Idem par 104-108.

96 It was uncontested that they are poor, that they lack the sophistication necessary to litigate individually, that they have no access to legal representatives and are constantly ill - see idem par 100.

97 Idem par 230 point 9

98 Idem par 85; 90-99; 119; 223.

99 Idem par 116; 119; 225.

100 Idem par 119.

101 Idem par 121.

102 Based on par 223; 225 and 230 point 10 
The split process envisaged by the court accords with the practice often encountered in America ${ }^{103}$ where members are required to 'opt in' in order to identify those who are to share in the award after liability has been determined (e.g. by submitting proof of claim), and is thus not used to establish a class. This distinction is important: a class action is an action on behalf of a group defined at the commencement date, and it is at that point that a right to opt out is conferred on them. A reference to 'opt in' after determination of liability (as envisaged in Nkala's stage one) is therefore not problematic as it does not change the initial regime (opt out in Nkala) - the original group or class description is unchanged, and it is only the number of persons who meet the class description that is affected. There is thus no 'new' members seeking inclusion in the class, and for this reason there is no opt-in in the conventional sense as referred to in the bimodal debate. (Hence the contention that one is in fact dealing with a hybrid version of the opt-out model.) As the term 'opt in' as used in the context of Nkala in respect of stage two may be confusing, such use should be avoided in future and descriptive wording be used instead. It is suggested that this matter has indeed laid the foundation for the adoption of an opt-out regime and an expansive approach.

\section{Conclusion}

The choice between implementing an opt-in or an opt-out model in a class action regime has been shown to be controversial when individualist ideals are pitted against ideals of greater participation by individuals through group litigation. These ideals need not be viewed as being in opposition and can co-exist as they are 'mutually vital components ${ }^{104}$ in a system which seeks to enhance access to justice. ${ }^{105}$ Choice, as stated above, is eventually determined by policy. ${ }^{106}$

Most common law jurisdictions have placed a strong emphasis on access to justice values, and have consequently adopted the opt-out model which appears to be a natural choice: because of its inclusive effect it gives expression to access values. The only common law system to date in which the opt-in model is used - albeit not in a strictly class action context - has provided evidence of its unsuitability as a model, and criticism is no longer confined to academic commentary. ${ }^{107}$ Thus far

103 See Friedenthal Kane and Miller Civil Procedure (2005) par 16.6.

104 See e.g. Friedman 'Constrained individualism in group litigation: requiring class members to make a good cause showing before opting out of a Federal class action' 1990 Yale Law Journal 745763.

105 A Valdes 'Procedure, policy and power: class actions and social justice in historical and comparative perspective' 2007 Georgia State University Law Review 627649 eloquently states: 'Throughout the zigs and zags of time, the virtue of the class action was and is in the effort to provide access to justice - to deliver justice to those who don't have access to justice. It is this virtue that motivates and justifies the modern class action specifically.'

106 See also Mulheron supra n 829.

107 See Mulheron supra $\mathrm{n} 38$ 556-557 where the drawbacks of such a model is discussed in the context of the British GLO regime. 
it appears (but is not yet firmly established) that South African developments are leaning towards the adoption of the opt-out model, motivated by access to justice values: in Mukaddam v Pioneer Food (Pty) $L t d^{108}$ the Supreme Court of Appeal indicated that the circumstances would have to be 'exceptional' before an opt in would be allowed, and in Nkala an opt-out was directed. Unfortunately, in the absence of class action legislation our courts have had to devise on a case-by-case basis solutions and develop procedural guidelines for a procedure that was given express constitutional recognition. Nkala will require further such court action, as the case will undoubtedly present numerous challenges to the trial court due to its size and complexity. This situation is undesirable, and a renewed call for legislation and supporting rulemaking is surely not amiss: legislation offers not only clarity and uniformity of practice and approach, but allows that matters of substantive law be dealt with. ${ }^{109}$ It is therefore recommended that such legislation specifically include a provision providing for the opt-out model similar to that contained in section 9 of the Ontario Class Proceedings Act, 1992. ${ }^{110}$ It is commendably brief and clear, yet efficacious in implanting access to justice values.

108 Supra $n 6$ 258F.

109 Mulheron supra n 8 38-42.

110 SO 1992 c6. It reads:

Opting out

9. Any member of a class involved in a class proceeding may opt out of the proceeding in the manner and within the time specified in the certification order. 